\title{
Some Indigenous stone arrangements in the south of Western Australia
}

\author{
Peter Randolph \\ Red-P Surveys, P.O. Box 302, Inglewood, Western Australia 6932, Australia \\ Email: redpsurveys@iinet.net.au; \\ Department of Anthropology, Western Australian Museum, Locked Bag 49, \\ Welshpool DC, Western Australia, 6986, Australia.
}

\begin{abstract}
This paper provides a brief description of a range of Indigenous stone arrangements that do not have an obvious utilitarian function and occur in the South-West and Murchison Regions of Western Australia. There has been relatively little research into stone arrangements in Western Australia and the detailed field recording of the Avon Downs Stone Arrangement made by Sylvia Hallam in 1970 stands out as one of the earliest recordings. As a newly appointed Graduate Assistant with the Department of Aboriginal Sites, Western Australian Museum, I turned Sylvia's field recording into a formal plan in 1973. This project triggered an ongoing interest in stone arrangements that I have intermittently pursued ever since.
\end{abstract}

KEYWORDS: site types, distribution, ceremonial function

\section{INTRODUCTION}

The Department of Indigenous Affairs (DIA) in Western Australia administers the Aboriginal Heritage Act 1972 (WA) and maintains a register of Aboriginal sites. 'Man-made Structure' is one of the types of Aboriginal site listed in the register and is defined as 'the placement or arrangement, by Aboriginal people of stone, wood or other material into a structure for ceremonial or utilitarian purposes'. Stone arrangements are a relatively common site type in the southern parts of Western Australia, but have received little attention from archaeologists and are poorly understood. Some interpretations have been posited, but in most instances their specific purpose is unknown.

It should be noted that there are many other stone arrangements registered with DIA for the State as a whole. In the south of the state, stone arrangements have been briefly described in the Perth Metropolitan area (Schwede 1990), the Jerramungup area (Bird 1985) and east of Esperance (Smith 1993), while Dix (1973: 45-46) indicates the general distribution of known stone arrangements in the southern part of Western Australia.

In this paper I use key examples to describe the range of stone arrangements reported from the region and discuss some of the interpretations that have been suggested for them. My main focus is on non-utilitarian arrangements rather than functional stone arrangements such as fish traps, hunting hides or hut bases.

Stone arrangements from the south of Western Australia are very diverse in form. The main types are:
1. Standing stones - set in the ground, wedged in crevices or supported by other stones.

2. Cairns - simple piles, piles added to for ceremonial purposes, mounds or ridges of stones.

3. Lines/walls - continuous rows, multiple tier rows, discontinuous rows, straight/ curved/meandering rows.

4. Compound sets - combinations of some or all the above.

5. 'Lizard traps' - slabs of granite placed on or propped up by low dry stone walls or smaller exfoliated pieces to make a cavity beneath them. The status of these sites is controversial.

This diverse range is best illustrated here by presenting examples of each type. There are a small number of published descriptions of some of these sites, some of which include interpretations of the cultural purpose or meaning of the stone arrangements (see discussion below). Regrettably my own fieldwork did not generally include consultation with relevant Indigenous people so I have limited my discussion to the physical descriptions of the arrangements rather than making interpretations. In addition, because of the cultural sensitivity of some of the arrangements I have provided only the broadest locational references. Figure 1 shows the approximate locations of sites described here and listed in Table 1. 
TABLE 1 Sites referred to in the text and shown on Figure 1.

\begin{tabular}{|c|c|c|c|c|c|}
\hline $\begin{array}{l}\text { KEY TO } \\
\text { FIGURE }\end{array}$ & $\begin{array}{l}\text { DIA } \\
\text { SITE ID }\end{array}$ & $\begin{array}{l}\text { SITE } \\
\text { NAME }\end{array}$ & $\begin{array}{l}\text { KEY TO } \\
\text { FIGURE }\end{array}$ & $\begin{array}{l}\text { DIA } \\
\text { SITE ID }\end{array}$ & $\begin{array}{l}\text { SITE } \\
\text { NAME }\end{array}$ \\
\hline 1 & $\begin{array}{l}\text { DIA } 3268 \\
\text { DIA } 3485\end{array}$ & $\begin{array}{l}\text { Avon Downs } 1 \\
\text { Avon Downs } 2\end{array}$ & 11 & $\begin{array}{l}\text { DIA } 2846 \\
\text { DIA } 10748\end{array}$ & $\begin{array}{l}\text { Yeelirrie } 20 \\
\text { Yeelirrie } 23\end{array}$ \\
\hline 2 & DIA 5825 & Coralling Springs & & DIA 10755 & Yeelirrie 30 \\
\hline 3 & DIA 5353 & Jinka's Hill & 12 & DIA 11479 & Yeelirrie 16 \\
\hline 4 & DIA 5937 & Kunturu & 13 & $\begin{array}{l}\text { DIA } 5940 \\
\text { DIA } 5668\end{array}$ & $\begin{array}{l}\text { Bimbijy Station } 1 \\
\text { Bimbijy } 3\end{array}$ \\
\hline 5 & DIA 5568 & Canna & 14 & DIA 5932 & Monger's Lake \\
\hline 6 & DIA 5713 & Dongorie 1 & & & \\
\hline 7 & DIA 3155 & Kuru-Mi & 15 & DIA 1389 & Weebo 2 \\
\hline 8 & $\begin{array}{l}\text { DIA } 11047 \\
\text { DIA } 11048\end{array}$ & $\begin{array}{l}\text { Boolathana West Claypan } \\
\text { Boolathana Claypan }\end{array}$ & 16 & DIA 11482 & $\begin{array}{l}\text { Yeerlirrie } 19 \text { Stone Arr. } 3 \\
\text { (Sawyer's Mill) }\end{array}$ \\
\hline 9 & DIA 10777 & Bulli Bulli Claypan & 17 & DIA 10744 & Booylgoo Stone \\
\hline 10 & DIA 10858 & $\begin{array}{l}\text { Kalli Stone } \\
\text { Arrangement }\end{array}$ & & & gemen \\
\hline
\end{tabular}

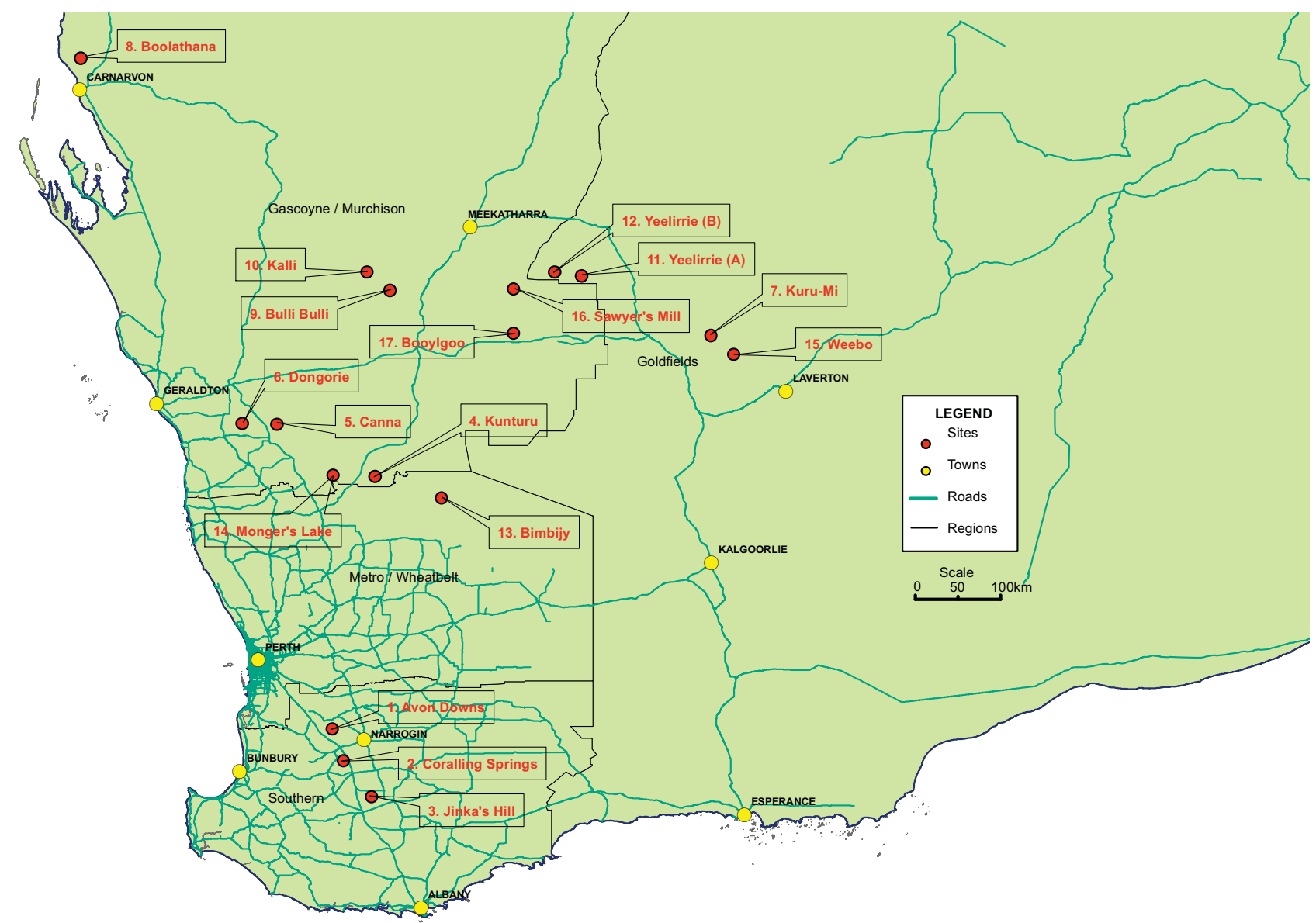

FIGURE 1 General location of sites referred to in the text. 


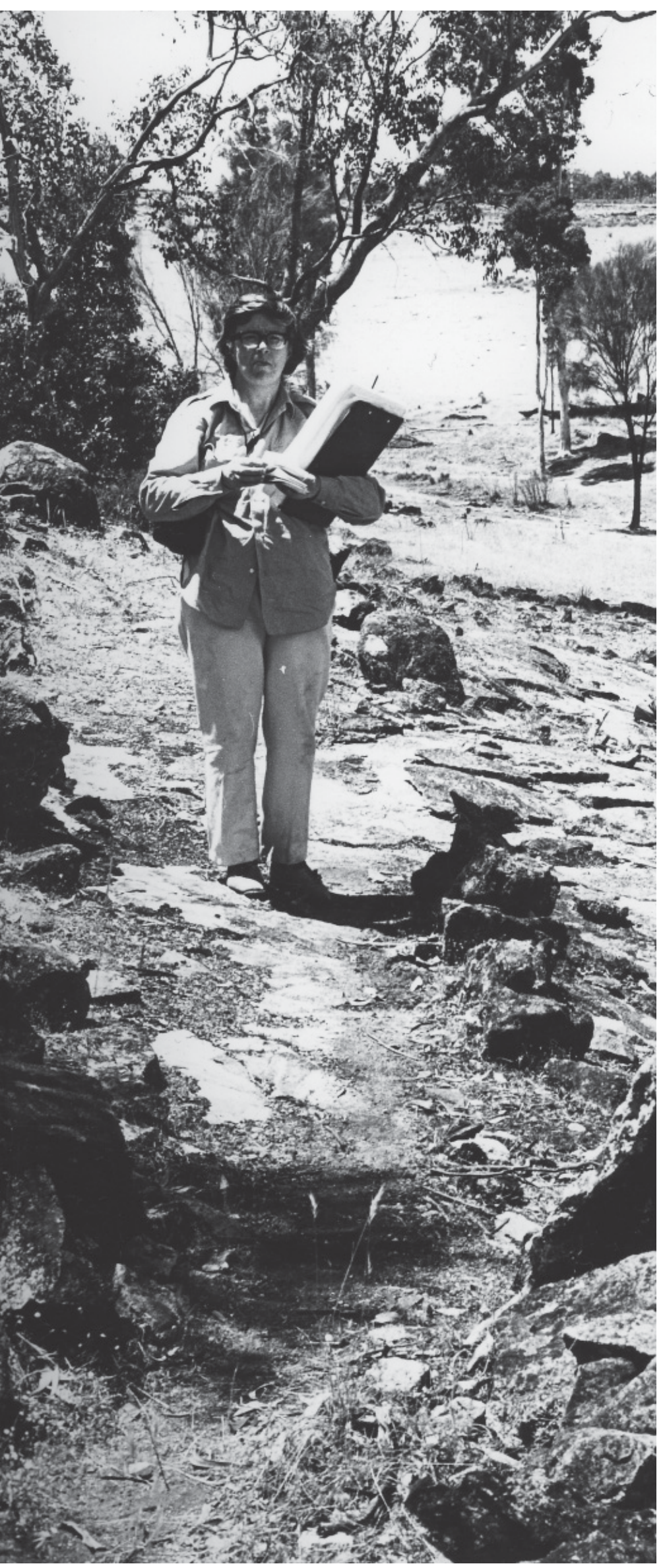

FIGURE 2
Sylvia Hallam at the Avon Downs Stone Arrangement. (Photo: Bruce Wright.)

\section{HOW IT ALL BEGAN}

\section{AVON DOWNS}

In 1970, Sylvia Hallam, then Lecturer in Archaeology at the University of Western Australia (UWA), surveyed the stone arrangement at Avon Downs, a farming property in the South-West of Western Australia. The alignment consists primarily of two parallel lines of standing stones and other aligned stones approximately $100 \mathrm{~m}$ in length that cross a small knoll so that neither end of the alignment is visible from the other end (Figures 2 and 3). In this respect the form of the Avon Downs Stone Arrangement has some similarities with the Bora Rings of south-eastern Queensland (Kate Sutcliffe, pers. comm. - formerly head of the heritage unit in the Department of Aboriginal and Islander Affairs, Queensland). The stones are locally available granite and at the time the arrangement was surveyed there were 24 standing stones and a further seven that were interpreted by Sylvia as fallen stones. The standing stones ranged in height from 14" (36 mm) to 31" (80 mm).

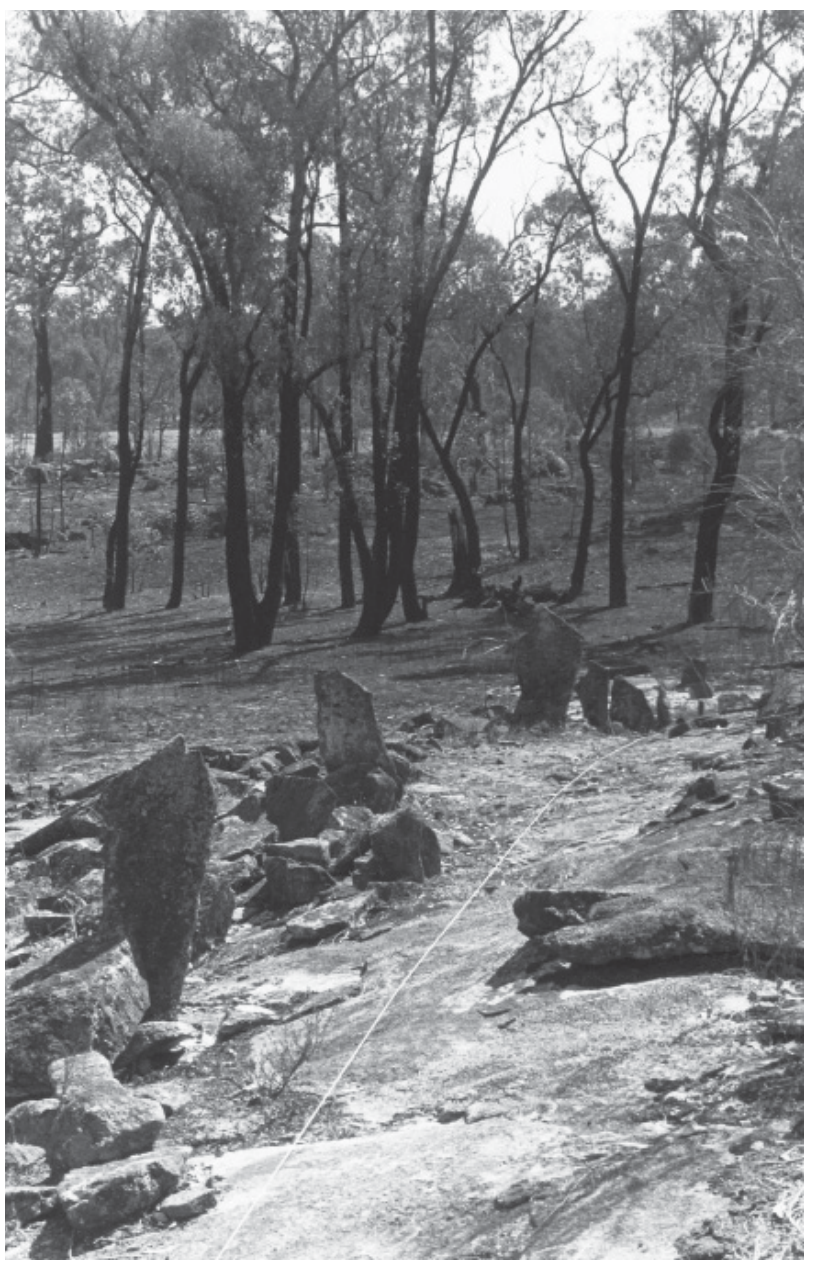

FIGURE 3
Avon Downs Stone Arrangement. (Photo: Sylvia Hallam.) 


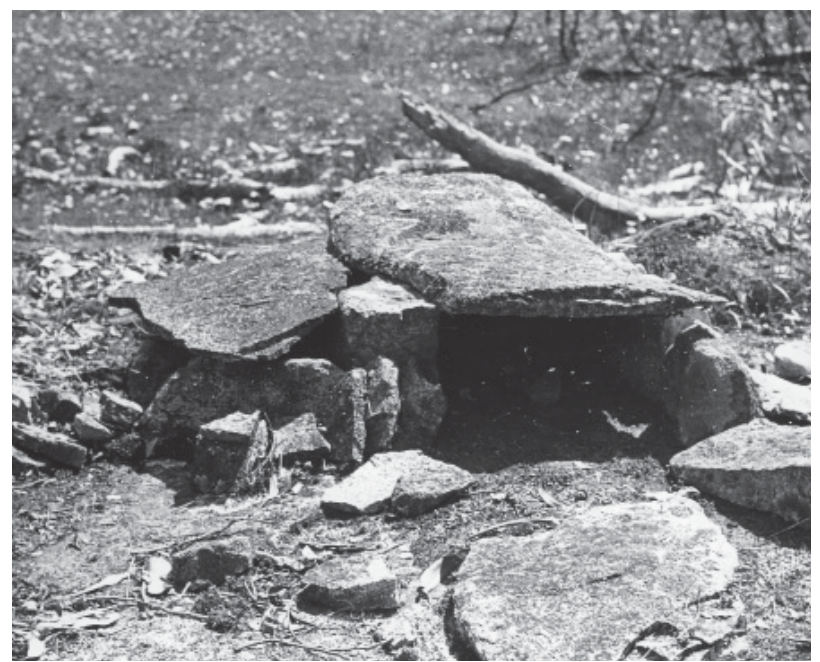

FIGURE 4

A typical 'Lizard trap'. (Photo: Sylvia Hallam.)

There are seven enigmatic structures alongside the alignment (Figure 4). These small (c. $90 \mathrm{~mm}$ x $90 \mathrm{~mm}$ ) structures consist, in the main, of low three-sided dry-stone walls of small thin exfoliated granite pieces that are covered by a single slab. One interpretation of these structures is that they replicate the circumstances where quite large exfoliated slabs - that frequently occur on granite domes - have small cavities under them that are a common habitat for small lizards. These structures have therefore been called 'lizard traps'. However, to the best of my knowledge, there is no substantive evidence that these structures were built for the purpose of trapping lizards. Interestingly, near one end of the alignment of standing stones is a linear arrangement of small single granite stones on an open rock platform that appears to be a large plan view of a 'lizard trap'. There may therefore be a ceremonial link between this structure and the 'lizard traps'.

As a Graduate Assistant with the Department of Aboriginal Sites, Western Australian Museum, I was requested to produce a plan of the Avon Downs Stone Arrangement from Sylvia's field recording. I visited the site prior to working on the plan and also visited a nearby site with a variety of 'lizard traps'. One had a wooden lintel to support the slab covering the walls, another had two slabs forming the cover and a third was an exfoliated slab propped up at its leading edge by some drystone piles (Figure 5). Another site with a 'lizard trap' is at Coralling Spring about $80 \mathrm{~km}$ from Avon Downs. Other such features have been recorded elsewhere in the South-West in the Jerramungup area and as far east as Esperance (Dix 1973; Bird 1985; Smith 1993).

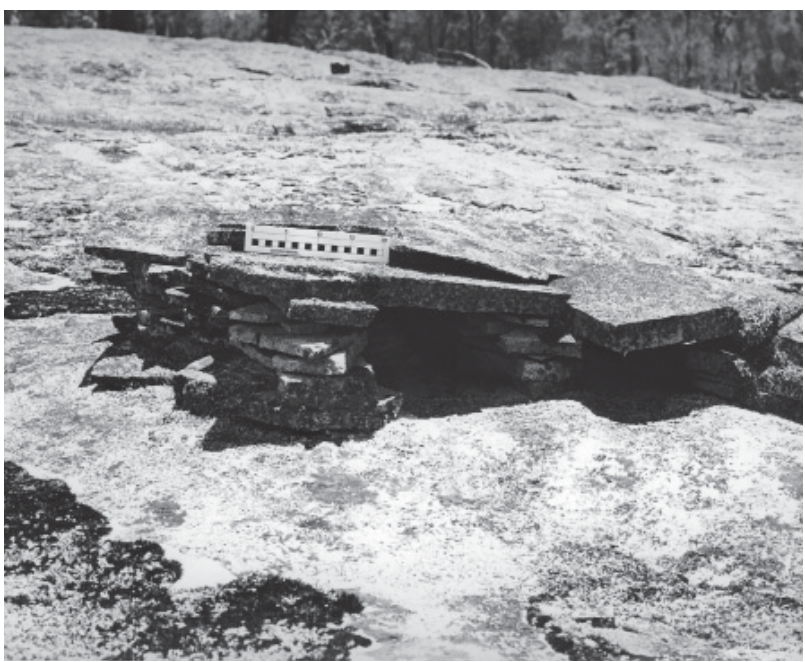

FIGURE 5

Another typical 'Lizard trap' from a nearby site. (Photo: Joseph Wallam.)

\section{OTHER STONE ARRANGEMENTS INTHE SOUTH OF WESTERN AUSTRALIA}

My appetite whetted, I took the opportunity to visit other known stone arrangements, particularly in the South-West and Murchison. Descriptions of some of these have been published previously, but others have not been published.

\section{JINKA'S HILL}

In Sailormen's Ghosts, a factually based novel by Malcolm Uren (1980: 38), there is an 1875 description by A.E. Burt of a stone arrangement. The arrangement is purported to be a circle of stones, evenly laid in a cleared space about $4.5 \mathrm{~m}$ across. A further description of the same arrangement dating to the 1930s is also provided (Uren 1980: 42). A line or lines of stones are said to point the way to the circle but discrepancies in the descriptions make it impossible to provide an accurate picture. This arrangement is apparently not far from the coast near Cockleshell Gully about $200 \mathrm{~km}$ north of Perth and is thought by some to designate the location of treasure buried by shipwrecked Dutch sailors. Uren (1980: 48-49), however, attributes the arrangement to Aboriginal people. I have never seen this arrangement, but the possibility of treasure buried within a similar arrangement led to the excavation within the stone arrangement at Jinka's Hill as a footnote by Uren (1980: 50) describes:

R.W.A. Warren, of Kalannie, states he was warned by the Aboriginal people of Katanning that the devil of Jinka's Hill, where a circle of stones was located, would catch him some day. However, $\mathrm{Mr}$ Warren had visions of doubloons and pieces of eight and got Mr George Biloton to dig for them. 
He found that the ground beneath had never been disturbed.

Caroline Bird (then with the Department of Anthropology, UWA) and I (then with the Department of Aboriginal Sites, WA Museum) became enmeshed in a revival of the claim that the stone arrangement at Jinka's Hill near Katanning could be the location of buried treasure. Our attempts to ensure the preservation of the site in the face of a gold mining proposal were frustrated by a zealous journalist who, until we approached the Australian Journalists Association, would not publish the archaeological interpretation. The middle of the arrangement was indeed disturbed (perhaps by Mr Biloton). However, other nearby features (i.e. a scarred tree and a possible ochre source) indicated a likely Aboriginal origin for the arrangement. I did endeavour to follow up $\mathrm{Mr}$ Warren's statement with an elderly Noongar man from the region, but other than to confirm that the term Jinka is a reference to a 'devil', he was unable or unwilling to elaborate on Jinka's Hill itself or the stone arrangement.

\section{KUNTURU}

Described by Richard Gould (1968, 1969), Kunturu is one of the most dramatic stone arrangements I have ever seen, nationally or internationally. The alignment consists of 437 upright and 91 fallen, dark, elongated pieces of schist arranged in a spiral that tapers off across the stark white of a dried salt lake. The design achieves a remarkable aesthetic effect. The spiral itself encloses a cluster of quartz boulders imbedded at its centre. Four smaller lines of upright stones alert anyone approaching along the lake shore. The totality of the site is awe inspiring.

In 1973 I helped coordinate the post ANZAAS (Australian New Zealand Association for the Advancement of Science) site tour, on which Sylvia and her late husband Herbert (then Professor in Ancient History) were participants. Kunturu was the first significant site we visited outside the metropolitan area. Kunturu is equally spectacular when the lake is flooded with water; however, the site is not illustrated here because it has 'Closed' status in the DIA Aboriginal Sites Register. Anyone who wishes to view the photographs held by DIA should seek the permission of the Badimia Native Title Claimants.

\section{CANNA}

Vincent Serventy and S. White (1958) described the Canna Stone Arrangement. There are a number of individual arrangements set out on almost every exposed flat rock surface which 'usually consisted of strings of stone fragments arranged in lines roughly parallel and joined at the western ends by a semi-circle or loop. There were numerous deviations and combinations of this theme, but the overall impression of this figure is typical' (Serventy and White 1958: 89). Circles were also common, and at one end of the area was a line of stone slabs, three of which were standing but the remainder lay flat, partly covered by soil although 'their appearance indicated they had fallen from a vertical position'. The principal and most intact alignment visible when I visited Canna in the 1970s consisted of a continuous line of small granite boulders on an open granite platform that forms an elongated ellipse with two circles of stones adjacent to one end and a smaller circle at the other. The arrangement is near a dominant 'pillar' of natural granite that has the appearance of a circumcised phallus that is visible for a considerable distance. Serventy and White make qualified reference to the phallic nature of the 'pillar' and at least one of the arrangements.

In addition to the linear arrangements there are hollowed out areas along the margins of the rock platforms. Serventy and White indicate that the eastern or elevated sides [of the rock platforms] are fringed with barriers of piled rock fragments, apparently the result of some natural physical process. There are, however, along these ramparts numerous depressions about four or five feet (c. 1.5 $\mathrm{m})$ across and up to three feet (c. $1 \mathrm{~m}$ ) deep which have the appearance of having been constructed by human hands' (Serventy and White 1958: 90). I have seen depressions of the kind described at a relatively nearby site on Dongorie Farm, recorded by the late Rev. Don McCaskill and Mr Bert Keeffe. The features could represent many things. However, at the Dongorie site the proliferation of a yam species that grows as a vine raises the interesting possibility that the depressions were the result of the harvesting of yams. With Dr Ian Crawford, I have noted the production of features of similar dimensions as those at Canna and Dongorie at Putairta Hill in the far north Kimberley, when women from Kalumburu were digging for yams by tracking the dried vines down through the rocks and soil.

Some might link the description of the Canna Stone Arrangement to thalu or increase sites or even go further and link the phallic shape of yams with the 'pillar' and the stone arrangements. Of course, without first-hand advice such interpretations are extremely imprudent; nevertheless, the Canna Stone Arrangement is not illustrated here because of the interpretation placed upon it by Serventy and White.

\section{KURU-MI}

The Kuru-Mi Stone Arrangement is described by Dix and Lofgren (1974). It consists of two distinct parts. On the edge of a freshwater clay pan that is often dry is a line of quite large dark stones with several other stones seemingly randomly placed behind it. In front of the line, some distance out on the clay pan, are two other stones (Dix and Lofgren 


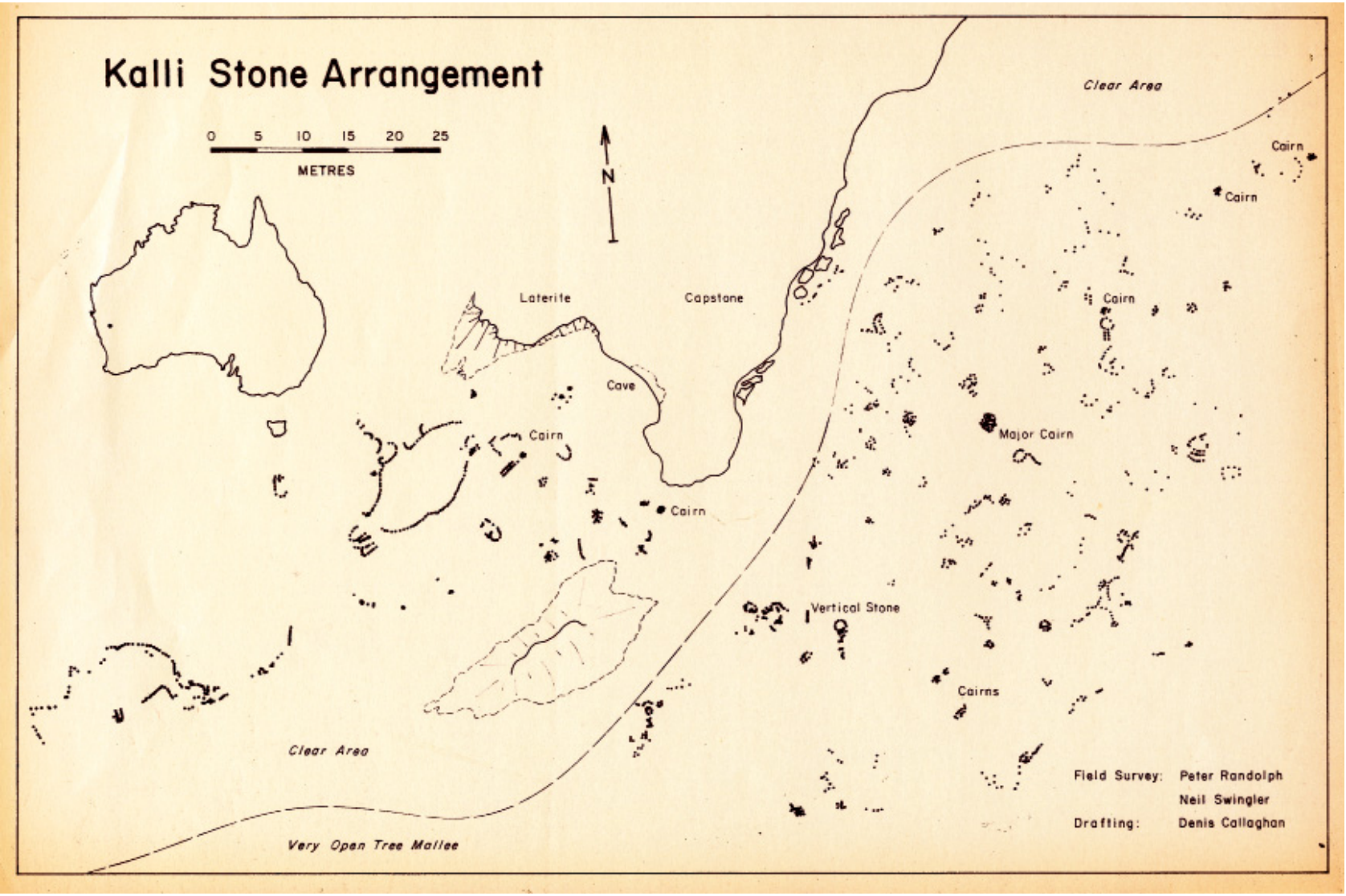

FIGURE 6

Kalli Stone Arrangement (drafted by Denis Callaghan).

1974: 73). On a sand dune on the margin of the clay pan there are several cairns of stones of varying sizes (Dix and Lofgren 1974: 76). Dix and Lofgren interviewed local Indigenous people about the arrangement. They were told that the line of stones represented a wind-break behind which various community members waited while a husband and wife, who had appropriate rights, went out onto the clay pan to harvest and prepare the seeds of the Tecticornia arborea, a plant that grows on the clay pan. The seeds of Tecticornia arborea are edible; they are ground up and made into a seed cake that is baked in the coals. The second arrangement consisting of several cairns is a dancing inma. Dix and Lofgren were told that following the meal the men conducted an important ceremony in the area where the cairns are located. Although all the plants were dead when Dix and Lofgren visited the site, one of their informants had a tobacco tin full of the seed which, it is understood, were to be broadcast in the cracks of the clay pan when rain was anticipated.

\section{BULLI-BULLI}

Linked to Kuru-Mi by virtue of the occurrence of Tecticornia arborea are at least two other clay pans. The dune surrounding the clay pan at Boolathana, relatively close to the coast near Quobba north of Carnarvon, has evidence of occupation and grinding, but not of stone arranging. Bulli-bulli claypan, however, has both. Bulli-bulli, west of Cue, is described briefly in a note by Pat Lindsey (1969). Her account makes little reference to the stone arrangements. Bulli-bulli is also referred to by Daisy Bates (1966) although it is unclear if she visited the site. The stone arrangement consists of several low, diffuse cairns of stones and some nearby randomly scattered stones that appeared to have been disturbed by stock when I visited it in 1969 with a contingent of students from the Western Australian Anthropological and Sociological Students Association.

The Department of Indigenous Affairs record suggests that the cairns were formed by Aboriginal people who placed a stone on the pile each time they visited the site. Unfortunately the statement is unsourced but it would not be unreasonable to extrapolate such an interpretation from sites in Central Australia, such as Gould's (1969: 162) illustration of a stone arrangement that he describes as a kampurarpa (wild tomato) increase site.

\section{KALLI}

While in the Murchison in the early decades of the twentieth century, Bates (1966: 113) makes reference to a stone man lying down. Bates 


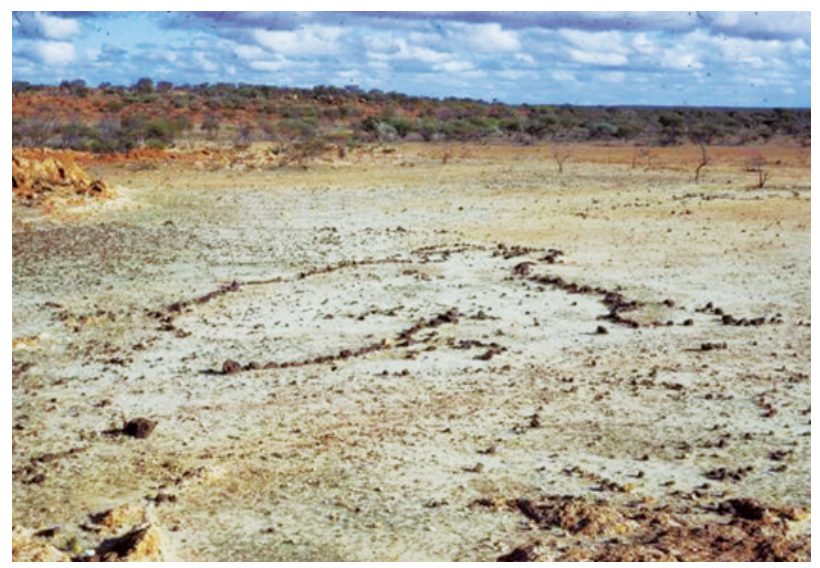

FIGURE 7

Principal figure at the Kalli Stone Arrangement. (Photo: Peter Randolph.)

describes a journey by dray to a place called Mindoola 80 miles (c. $130 \mathrm{~km}$ ) from Cue and records the following:

I had previously learned from the natives [sic] of a 'stone man lying down,' a dark scoriated heap of stone boulders that, from one aspect, appeared to be a gigantic recumbent figure. Should strangers approach the place, according to native [sic] belief, the stone man rose in anger, and they died, for the stone sleeper was Barlieri, a legendary father. As we approached this, I gazed on it intently. 'You see,' I said in an undertone to the native [sic] by my side, 'Barlieri knows me. He knows I am coming. He is glad. He does not rise against me.' I felt the native [sic] gradually edging closer.

I am reasonably confident she was referring to a stone arrangement at Kalli. With the help of $\mathrm{Mr}$ Neil Swingler I mapped this incredibly complex arrangement. I believe the arrangement includes the remnants of two sets of alignments that are essentially the same (i.e. the principal figure and another to the south-west). In addition, some elements of the many arranged stones to the east may also be the remnants of a similar but now deconstructed figure. Perhaps this figure is Barlieri, 'the stone sleeper'. I am therefore of the opinion that these various arrangements may represent stone arranging at different times.

The principal figure consists of lines of small boulders mostly abutting one another to form a seemingly amorphous unenclosed shape approximately $20 \times 15 \mathrm{~m}$, with two roughly elliptical additions at one end (Figures 6 and 7). In addition there are numerous short lines and small clusters of stones as well as several cairns. The whole complex is on a flat area to the south of a low breakaway. The breakaway has a small overhang/ cave close to the principal figure.

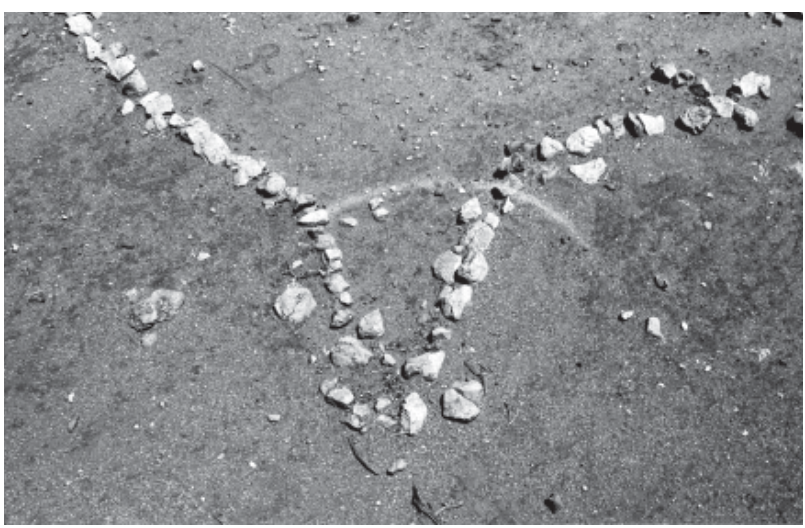

FIGURE 8

Yeelirrie Site 20. (Photo: Peter Randolph.)

The complexity of the totality of the arrangements, and the likelihood that some of the arrangements have been dismantled to create new alignments, makes any kind of interpretation difficult. However, if Bates' reference to a stone man lying down is related to this stone arrangement it may suggest a link to male ritual. Regrettably there is little likelihood of confirming such an interpretation.

\section{YEELIRRIE}

At several locations in the Murchison there are linear arrangements that consist of, or include, an asymmetrical ' $\mathrm{V}^{\prime}$ or ' $\mathrm{W}^{\prime}$ as part of the pattern of stones. During one of the first specifically Aboriginal heritage studies undertaken in Western Australia at Yeelirrie (Department of Aboriginal Sites 1976) several stone arrangements were noted. Three arrangements provide examples of this type - Yeelirrie site 20, 23 and 30 (Figure 8).

Other such arrangements have been observed at Bimbijy (Figure 9), discussed below, and at Monger's Lake (Figure 10). Anecdotal evidence suggests the pattern represents the vulva of a kangaroo (Warwick Dix, pers. comm.). I am unable to confirm or deny this interpretation and it is confounded in part by advice I have received from one elderly informant. His view, in relation to a distorted ' $\mathrm{V}$ ' shaped arrangement, is that if he saw a stone arrangement with one long and one short arm, the long arm will always points to water (Bill Pearce, pers. comm.). Unfortunately, although many stone arrangements are sited near water sources, the evidence does not support this interpretation. Steve Brown (1979) was told by the owner of Bimbijy that a now deceased Aboriginal informant had indicated that the ' $\mathrm{V}$ ' shape was a sign for the area. There is no doubt that there are several alignments with this form on Bimbijy Station; however, it is also true that the symbol is quite widely spread and, to the best of my knowledge, 


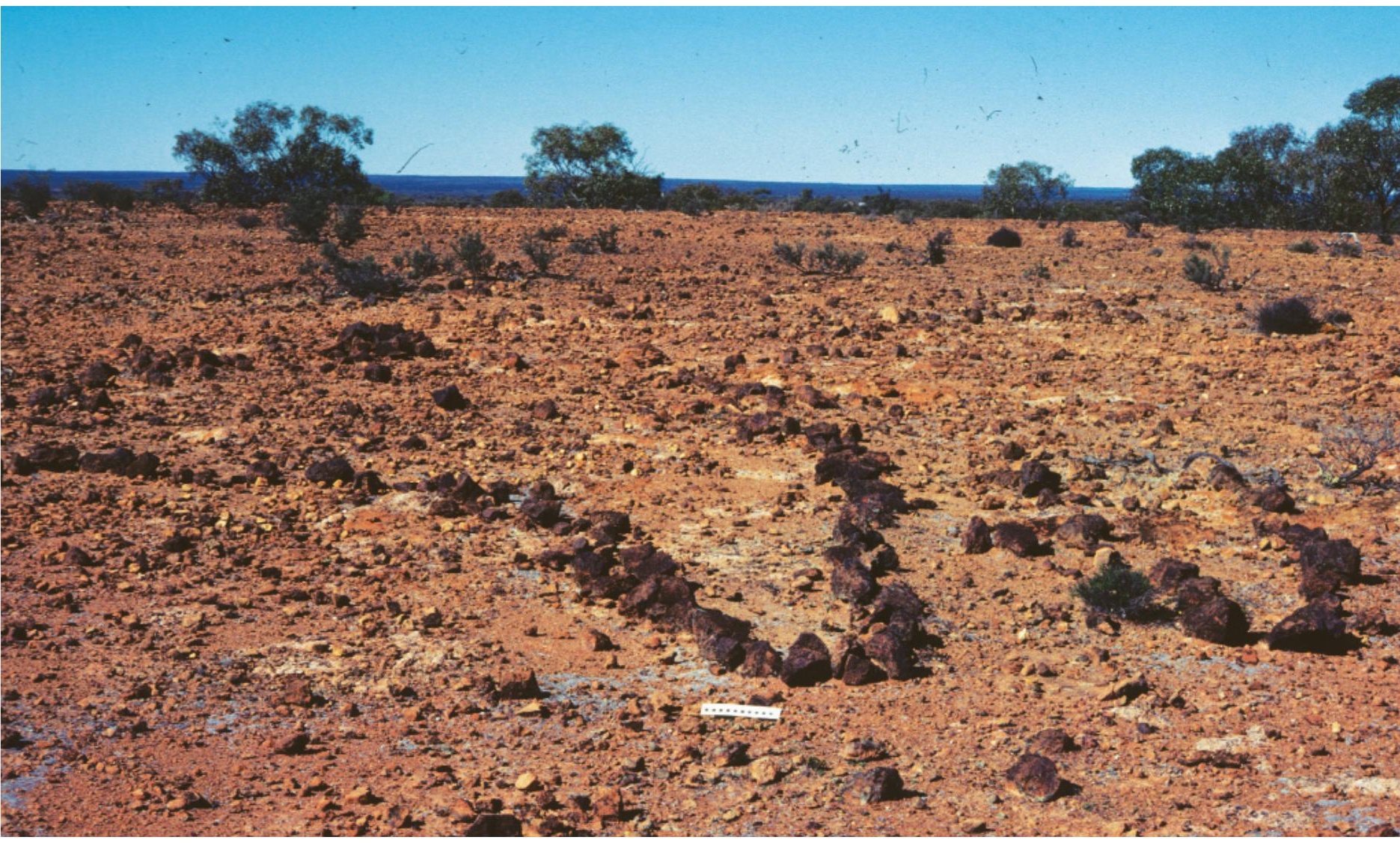

FIGURE 9

A stone arrangement at Bimbijy. (Photo: Peter Randolph.)

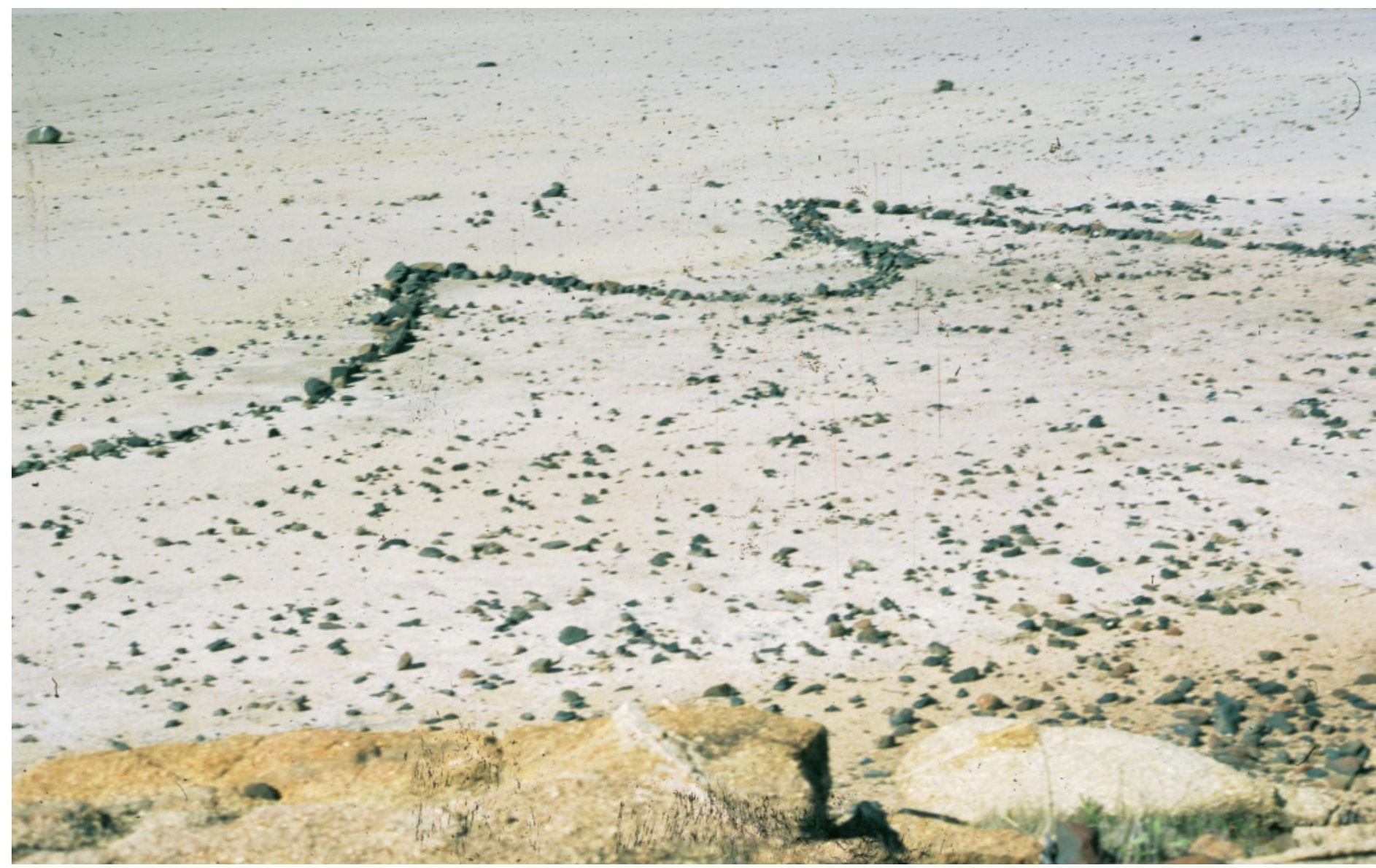

FIGURE 10 A stone arrangement at Monger's Lake. (Photo: Peter Randolph.) 


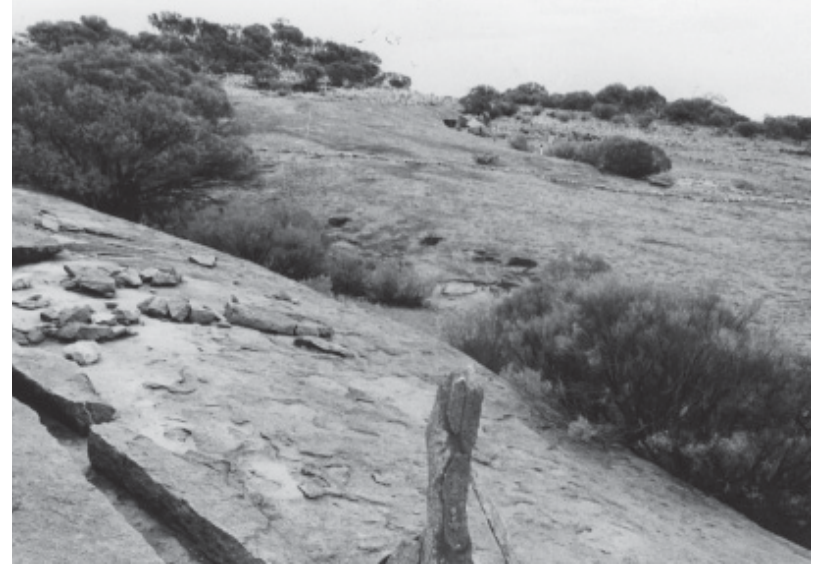

FIGURE 11

Section of circular arrangement Yeelirrie 16. (Photo: Peter Randolph.)

includes locations that are in different dialectical and probably cultural areas.

In the Yeelirrie examples the arrangements are single lines of dark stones that contrast with the light coloured soil on flat open areas. At Bimbijy the contrast is less distinct because the stones in the alignment are often a similar colour to the surrounding rocky ground. At Monger's Lake some arrangements are located in similar situations to those at Bimbijy with little contrast between the stones and the ground but there are also some that are situated on the lake bed and the contrast between the rocks and the dried, salt encrusted surface is very distinct. In all cases there are additional alignments (e.g. short lines of stones) nearby.

In the report for the Yeelirrie Uranium Project (DAS 1976) there is also reference to a completely different arrangement in a completely different setting (Figure 11). This arrangement is a very large, almost complete circle of small granite stones on an extensive sloping granite outcrop. One end of the alignment joins a natural alignment where a row of granite blocks has exfoliated. At the other end of the alignment there is a group of elongated stones that have been interpreted as a collapsed vertical stone and supports. There are several propped up standing stones and another collapsed vertical stone $55 \mathrm{~m}$ from the centre of the main arrangement (Figure 12).

\section{WEEBO}

At Weebo, site of the famed 'pavement' (the quarrying of which was said to be a key trigger for the enactment of the Aboriginal Heritage Act 1972), there is an extensive arrangement of standing stones on a rocky hillside about $1 \mathrm{~km}$ from the 'pavement'. Here, elongated slabs of schist, some over a metre tall, are propped up with a number of

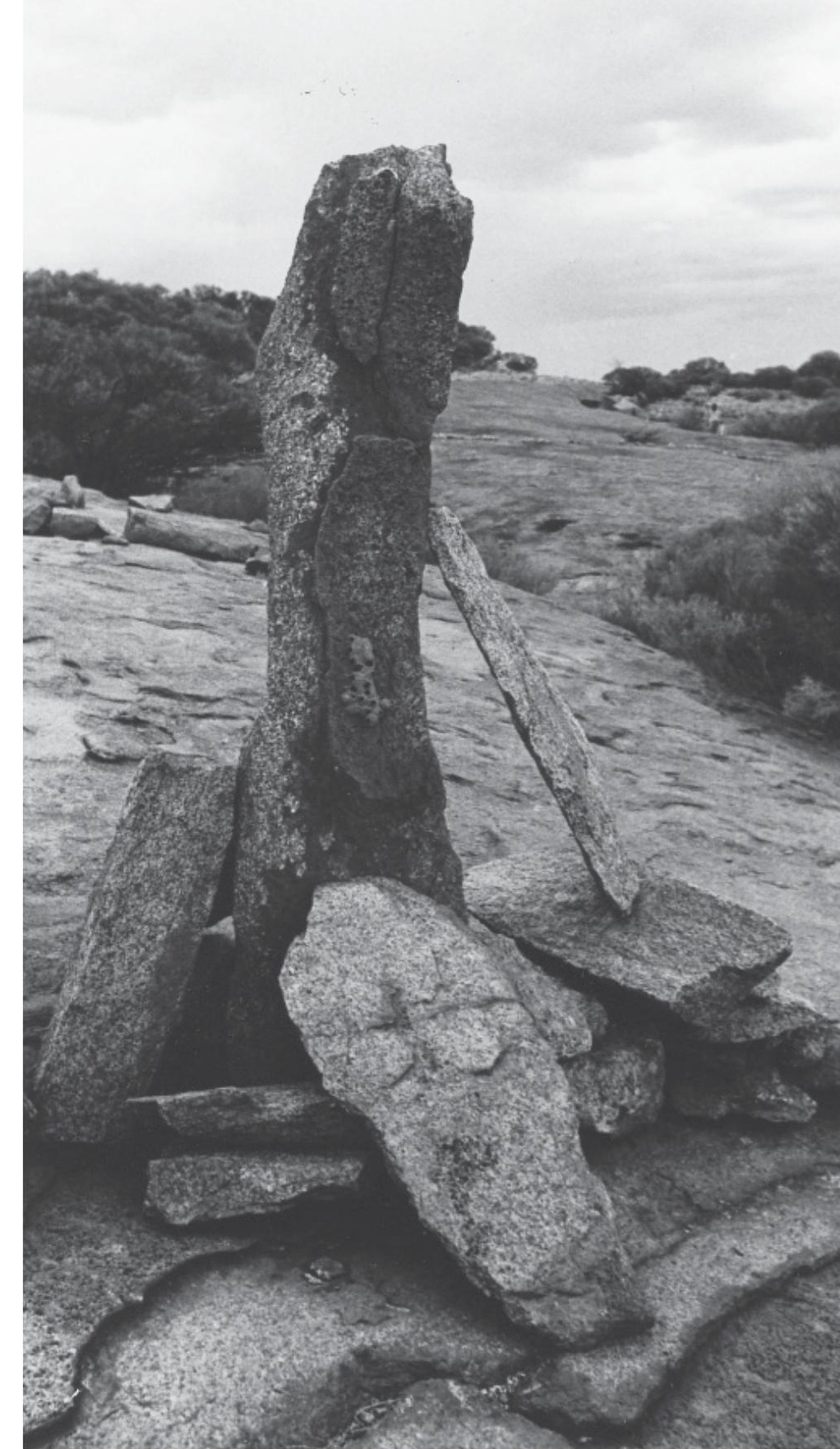

FIGURE 12 Supported standing stone - Yeelirrie 16. (Photo: Peter Randolph.)

smaller stones that are wedged tightly around the base of each upright stone.

The arrangement is quite extensive; however, it has not been accurately surveyed. I have not included an illustration because of the cultural sensitivity of the overall Weebo complex.

\section{SAWYER'S MILL}

The arrangement close to Sawyer's Mill is another unique design. It is focused on several large granite 


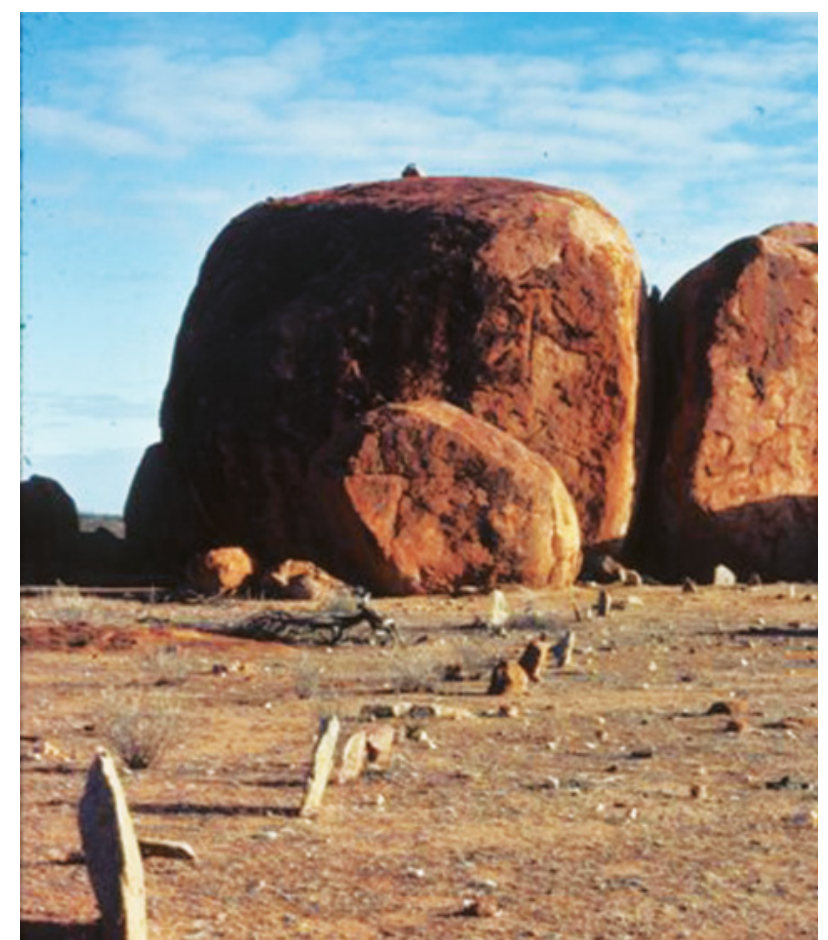

FIGURE 13

Sawyer's Mill stone arrangement. (Photo: Peter Randolph.)

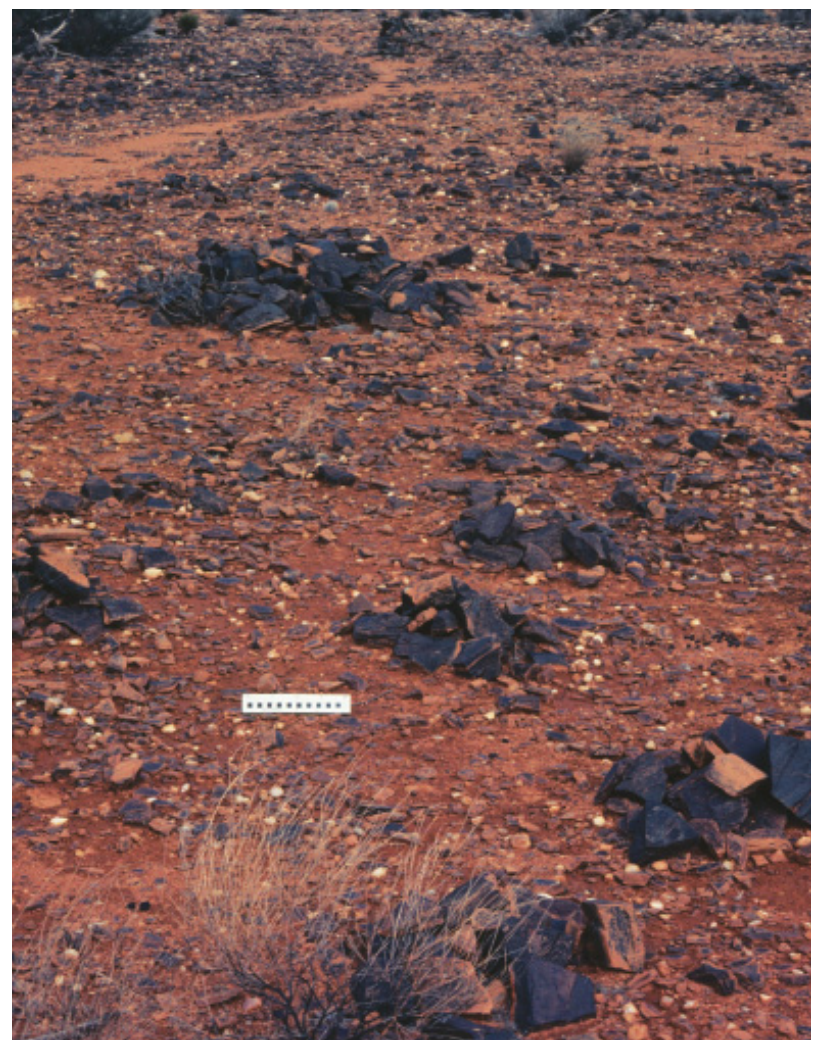

FIGURE 14

Booylgoo stone arrangement. (Photo: Peter Randolph.)

tors that dominate an otherwise flat sandy plain. It is described in the report of the Yeelirrie Uranium Project (DAS 1976). The large granite boulders are 7-10 $\mathrm{m}$ high and extend for approximately $70 \mathrm{~m}$. Alignments of stones extend about $35 \mathrm{~m}$ south,

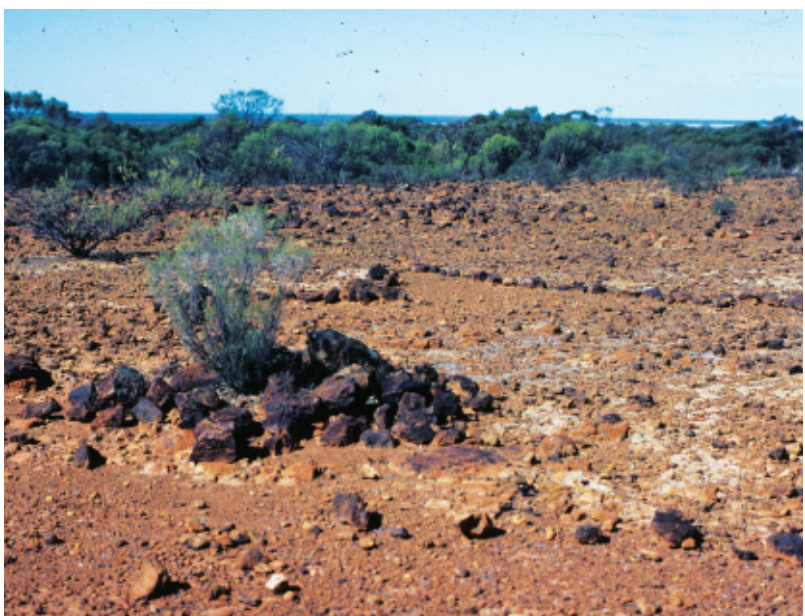

FIGURE $15 \quad$ Bimbijy stone arrangement.

(Photo: Peter Randolph.)

west and north of the boulders rocks. Several rocks are placed in trees to the east. Many of the rocks are flat, about $30 \mathrm{~cm}$ high, standing erect in the soil (Figure 13). Several have fallen over. There is a gnamma hole in an adjacent outcrop about $35 \mathrm{~m}$ east of the main outcrop (DAS 1976: 99).

There are at least four lines of stones in the overall arrangement. From a vantage point on top of the tors the effect is of lines of standing stones, about $2 \mathrm{~m}$ apart, radiating from a central point. A full survey has not been undertaken.

\section{BOOYLG00 AND BIMBIJY}

At Booylgoo the design is different again. Here, meandering lines of stones are interspersed with cairns (Figure 14). The lines are sometimes a parallel pair that appears to create a serpentine pathway. Overall the lines tend to be aligned in the same direction, reinforcing the pathway concept. There are similar arrangements at Bimbijy (Figure 15).

\section{CONCLUSION}

There are Indigenous stone arrangements throughout Western Australia; however, those I have visited in the South-West and Murchison Regions include an astounding variety. The arrangements described above demonstrate the creativity and ingenuity of the Indigenous peoples of these regions.

A possible explanation is the scarcity of suitable surfaces for other forms of artistic expression. There are paintings (including stencils and drawings) and engravings throughout these regions but major painted or engraved sites are rare. The painted and engraved sites are often in a poor state of repair because of the quality (friability or eroded state) of the underlying rock. Two very obvious examples are: (a) the friable quality of the kaolinised zone of most breakaways in which hand stencilling has 
occurred, and (b) the eroded, coarse, crystalline structure of most outcropping granite which makes it an unsuitable surface for engraving or painting.

On the other hand, the Indigenous people of the south of Western Australia appear to have excelled in the skill of arranging stones on open rock surfaces or flat sandy plains. Stone arrangements in the region are relatively common and this paper is merely an introduction to the wealth of material for further research. Such sites are also exceedingly vulnerable to human interference so high priority should be given to their recording and ongoing management.

\section{ACKNOWLEDGEMENTS}

I wish to thank: the Indigenous people of the South-West and Murchison who created the vast array of stone arrangements throughout the regions; Sylvia Hallam who triggered my interest in stone arrangements; Warwick Dix who allowed it to flourish; Neil Swingler who assisted with the field recording of the Kalli stone arrangement and Denis Callaghan who drafted the plans of several of the stone arrangements from my field recordings.

\section{REFERENCES}

Bates, D. (1966). The Passing of the Aborigines: a lifetime spent among the Natives of Australia. 2nd edition. Heinemann: Melbourne.

Bird, C.F.M. (1985). Prehistoric lithic resource utilization: a case study from the south-west of Western Australia. PhD thesis, University of Western Australia: Nedlands.

Brown, S. (1979). Manuscript field notes on file at the Department of Indigenous Affairs, Perth.

Department of Aboriginal Sites [DAS]. (1976). A survey for Aboriginal sites: Yeelirrie Uranium Project. Western Australian Museum: Perth.
Dix, W.C. (1973). Aboriginal art: ceremonial and other sites in southwestern Australia (p. 46). In: Merrilees, D., Dix, W.C., Hallam, S.J., Douglas, W.H. and Berndt, R.M. Aboriginal man in southwestern Australia. Journal of the Royal Society of Western Australia 56: 44-55.

Dix, W.C. and Lofgren, M.E. (1974). Kurumi: possible Aboriginal incipient agriculture associated with a stone arrangement. Records of the Western Australian Museum 3: 73-77.

Gould, R.A. and Gould, E.B. (1968). Kunturu, an Aboriginal sacred site on Lake Moore, Western Australia. American Museum Novitates 2327: 1-17.

Gould, R.A. (1969). Yiwara: foragers of the Australian desert. Collins: London - Sydney.

Hallam, S. J. (1970). Survey Report - Avon Downs Stone Arrangement. Unpublished paper lodged with Australian Institute of Aboriginal Studies, Canberra.

Hallam, S. J. (1975). Fire and hearth: a study of Aboriginal usage and European usurpation in South-western Australia. Australian Institute of Aboriginal Studies: Canberra.

Lindsey, C. P. (1969). Aboriginal Food Plants. Ilchinkinga: Journal of the Western Australian Anthropological and Sociological Student Association, University of Western Australia: Nedlands.

Serventy, V.N. and White, S.R. (1958). Stone arrangements at Canna, Western Australia. The Western Australian Naturalist 6: 85-92.

Schwede, M. (1990). Quartz, the multifaceted stone: a regional prehistory of the Helena River Valley on the Swan Coastal Plain of southwestern Australia. PhD thesis, University of Western Australia: Nedlands.

Smith, M.V. (1993). Recherche à l'Esperance: a prehistory of the Esperance region of south-western Australia. PhD thesis, University of Western Australia: Nedlands.

Uren, M. (1980). Sailormen's ghosts. 5th edition. Angus and Robertson: Australia.

MANUSCRIPT RECEIVED APRIL 2005; ACCEPTED JULY 2008. 